\title{
Residual Stress Analysis on Oxide Layers Obtained by High Temperature Oxidation of Chromia-Forming Alloys
}

\author{
Ning $\mathrm{LI}^{\mathrm{a}}$, Ji XIAOb , Nathalie PRUD'HOMME ${ }^{\mathrm{c}}$, Linwei $\mathrm{LI}^{\mathrm{d}}$ and Vincent $\mathrm{JI}^{\mathrm{e}^{*}}$ \\ ICMMO/SP2M, Université Paris-Sud, bat. 410, 91405 Orsay Cedex, France \\ a ning.li@u-psud.fr , bji.xiao@u-psud.fr , c nathalie.prudhomme@u-psud.fr, \\ dlinwei.li2@u-psud.fr , evincent.ji@u-psud.fr ,
}

\begin{abstract}
Keywords: High Temperature Oxidation, Residual Stress, Water Vapor, X-Ray Diffraction Stress Analysis, Chromia-Forming Alloy
\end{abstract}

\begin{abstract}
The oxide layers formed during high temperature oxidation of metallic alloys depend on experimental conditions (oxidation gas composition, gas pressure, temperature, duration etc...) and often with complex structure or multilayer structure. Residual stress can be generated not only dues to oxide growth at high temperature (growth stress) but also during cooling of layer/metallic alloy system after oxidation (thermal stress). The determination of the level and the distribution of the residual stresses in oxide layers are very important to determine the influence of oxidation condition in one hand and to estimate the mechanical component's durability at high temperature in the other hand. Two Chromia-forming alloys have been studied: a nickel based Inconel 600 alloy (Ni-17\%Cr$8 \% \mathrm{Fe}-1 \% \mathrm{Mn})$ and a ferritic AISI 430 steel $(\mathrm{Fe}-17 \% \mathrm{Cr}-1 \% \mathrm{Mn})$. Oxidation test has been carried out at different temperatures (from $600^{\circ} \mathrm{C}$ to $900^{\circ} \mathrm{C}$ ) for various durations (from $2 \mathrm{~h}$ to $96 \mathrm{~h}$ ) under different absolute humilities (from $0 \%$ to 19\%). After oxidation of Inconel 600, the oxide layers are composed essentially by an external $\mathrm{NiO}$ layer and by an internal spinel $\mathrm{NiCr}_{2} \mathrm{O}_{4}$ layer. While the AISI 430 steel forms an external spinel $\mathrm{Mn}_{1.5} \mathrm{Cr}_{1.5} \mathrm{O}_{4}$ layer and an internal $\mathrm{Cr}_{2} \mathrm{O}_{3}$ layer. The residual stresses (RS) have been analyzed by X-Ray Diffraction (XRD) method in each of oxide layers after oxidation tests. In oxide layers, the RS are compressive and the RS levels are more important in internal layer than those in external layer. Overall, the compressive RS in oxide layers increase with oxidation temperature, oxidation duration and absolute humidity.
\end{abstract}

\section{Introduction}

At high temperature, almost all metals are not thermodynamically stable in air or in atmosphere where oxygen exists, and a solid oxide scale will form on the surface. Oxidation of Chromia-forming alloys has drawn lots of attention in recent years, for their good oxidation resistance and low cost. It is true that lots of studies have been done to study the oxidation behavior of Chromia-forming alloy in dry air, but humidity exists in all stages of oxidation in reality. Therefore, studying the influence of water vapor on Chromia-forming alloys oxidation at high temperature has great importance. Some works have been done to study the influence of water vapor on oxidation [1-6], and several mechanisms have been proposed to explain the influence of water vapor on oxidation, such as Fuji and Meussner [2] proposed a dissociation mechanism, and suggested that hydrogen appears to play an important role in the oxidation process as an oxygen carrier between the separated inner and outer scale layers. Shen Jianian [3] suggested that breakaway oxidation happened in the water vapor containing atmosphere is the result of formation of microcracks and microchannels during oxidation. H. Asteman $[4,5]$ observed the evaporation of Chromia hydroxide. According to J. Ehlers the entry of molecular $\mathrm{H}_{2} \mathrm{O}$ into the oxide scale was the main process leading to breakaway oxidation [6]. Obviously, the mechanism of Chromia-forming alloys oxidation with water vapor is still a contentious question. 
It has been known that the residual stresses in the oxide scale are closely related to oxidation kinetic and the microstructure. Although some research works were already performed for Chromiaforming alloys to determine the residual stresses in the oxide scale after oxidation under dry air [7, 8], very few works were focused on residual stresses after oxidation in atmosphere with water vapor.

The purpose of this work was to investigate the influence of water vapor on Chromia-forming alloys at high temperature, and AISI 430 and Inconel 600 alloys were selected.

\section{Experimental}

The nominal chemical composition of the materials used in this study is listed in Table 1. Before oxidation, the samples were cut into a dimension of $10 \mathrm{~mm} \times 10 \mathrm{~mm} \times 1 \mathrm{~mm}$. All 6 surfaces of the samples were polished by $\mathrm{SiC}$ paper followed by silicon solution to make all the samples have the same surface state. Oxidation experiments were performed by thermal gravimetric analysis (TGA) (model SETARAM 92-16.18) under artificial air with different absolute humidity, and the precision of TGA analysis is more than $10^{-6} \mathrm{~g}$. For AISI 430 alloy, the oxidation temperature is $700^{\circ} \mathrm{C}-800^{\circ} \mathrm{C}$, and for Inconel 600 alloy the temperature is $600^{\circ} \mathrm{C}-900^{\circ} \mathrm{C}$. The regulation of absolute humidity is realized by using a vapor generator (SETARAM D/WETSYS-2F) and the sensibility of regulation is about $1.5 \%$ in relative humidity. To ensure the reliability of the experiments, every oxidation conditions has been conducted at least 2 times and the results were reproducible.

After oxidation, the samples were investigated by using FEG-SEM (Field Emission Gun-Scanning Electronic Microscope) / EDX (Energy-dispersive X-ray spectroscopy) (ZEISS SUPRA 55VP) to study the surface morphology and the cross section, and by Grazing Incident X-ray diffraction (GIXRD) to identify the oxide phase formed during the oxidation.

In this study, European standard NF EN 15305 (version of April 2009) [9] has been applied to determine the residual stresses levels in different oxide layers. In our experiments, a high resolution configuration XRD system (Panalytical X'Pert MRD Pro) was used under Copper radiation ( $\lambda=0.154$ $\mathrm{nm}$ ), whatever the relative low diffraction angle $2 \theta$, the determined peak position error is smaller than $0.005^{\circ}$ in $2 \theta$. For each selected plane family, more than 13 peaks are recorded. The calculation of the residual stress was performed via X'Pert Stress software. The precision for stress determination is about $30 \mathrm{MPa}$ under our experimental conditions. The details of the operation parameters for determining residual stresses by XRD method is given in Table 2 .

Table 1 Chemical composition of AISI 430 and Inconel 600 alloys (weight \%)

\begin{tabular}{ccccccc}
\hline \hline & $\mathrm{Fe}$ & $\mathrm{Cr}$ & $\mathrm{Mn}$ & $\mathrm{Si}$ & $\mathrm{S}$ & $\mathrm{C}$ \\
\hline AISI 430 & Bal. & $16-18$ & $<1.00$ & $<1.00$ & $<0.03$ & $<0.08$ \\
\hline Inconel 600 & $6-10$ & $14-17$ & $<1.00$ & $<0.5$ & $<0.015$ & $<0.15$ \\
\hline
\end{tabular}

Table 2 Operation parameters for determining residual stresses by XRD method

\begin{tabular}{cc}
\hline \hline Analyzed zone & $2 \mathrm{~mm} \times 2 \mathrm{~mm}$ \\
$\psi$ angle amplitude & {$\left[-60^{\circ} ; 60^{\circ}\right]$} \\
Number of $\psi$ angle & 13 \\
diffraction angle $2 \theta$ & $33.6^{\circ}$ for $\{104\}_{\mathrm{Cr} 2 \mathrm{O} 3}, 35.1^{\circ}$ for $\{311\}_{\mathrm{Mn} 1.5 \mathrm{Cr} 1.5 \mathrm{O} 4}$ \\
$2 \theta$ step & $63^{\circ}$ for $\{110\}_{\mathrm{NiO}}, 57^{\circ}$ for $\{511\}_{\mathrm{NiCr} 2 \mathrm{O}}$ \\
Acquisition time & $0.04^{\circ}$ \\
Peak position error & $15 \mathrm{~s} / \mathrm{step}^{\circ}$ \\
Young's modulus (GPa) & $0.005^{\circ}$ \\
& $\mathrm{Cr}_{2} \mathrm{O}_{3}: 280[10] ; \mathrm{Mn}_{1.5} \mathrm{Cr}_{1.5} \mathrm{O}_{4}: 250[11] ;$ \\
Poisson's ratio & $\mathrm{NiO}: 190[10] ; \mathrm{NiCr}_{2} \mathrm{O}_{4}: 280[10]$ \\
& $\mathrm{Cr}_{2} \mathrm{O}_{3}: 0.29[10] ; \mathrm{Mn}_{1.5} \mathrm{Cr}_{1.5} \mathrm{O}_{4}: 0.27[11] ;$ \\
\hline
\end{tabular}




\section{Results and discussion}

AISI 430 alloy. Figure 1 gives the $2^{\circ}$ GIXRD patterns of AISI 430 alloy after oxidation in air with different humidity at $700^{\circ} \mathrm{C}, 800^{\circ} \mathrm{C}$ for $96 \mathrm{~h}$. It is clear that the oxide scales are mainly consisted of $\mathrm{Cr}_{2} \mathrm{O}_{3}$ and $\mathrm{Mn}_{1.5} \mathrm{Cr}_{1.5} \mathrm{O}_{4}$ whatever the oxidation atmospheres, indicating that the water vapor doesn't affect the scale composition. The intensity of substrate peaks is larger in the atmosphere containing water vapor because the oxide scales formed during the oxidation are thinner than them formed in the dry air.

Observation of the cross section after oxidation in air with $5 \%$ absolute humidity at $800^{\circ} \mathrm{C}$ for $48 \mathrm{~h}$ by FEG-SEM is given in Figure 2, and it shows clearly that the oxide scale consisted of two layers. With the FEG-SEM observation and XRD analysis, we can conclude that the outer layer is $\mathrm{Mn}_{1.5} \mathrm{Cr}_{1.5} \mathrm{O}_{4}$ (with little $\mathrm{Fe}$ incorporation) and the inner layer is $\mathrm{Cr}_{2} \mathrm{O}_{3}$. Moreover, formation of thin and discontinuous $\mathrm{SiO}_{2}$ was also observed at the scale/substrate interface. Isolated voids were found at the scale/substrate interface, which may be result from outward diffusion of ions.
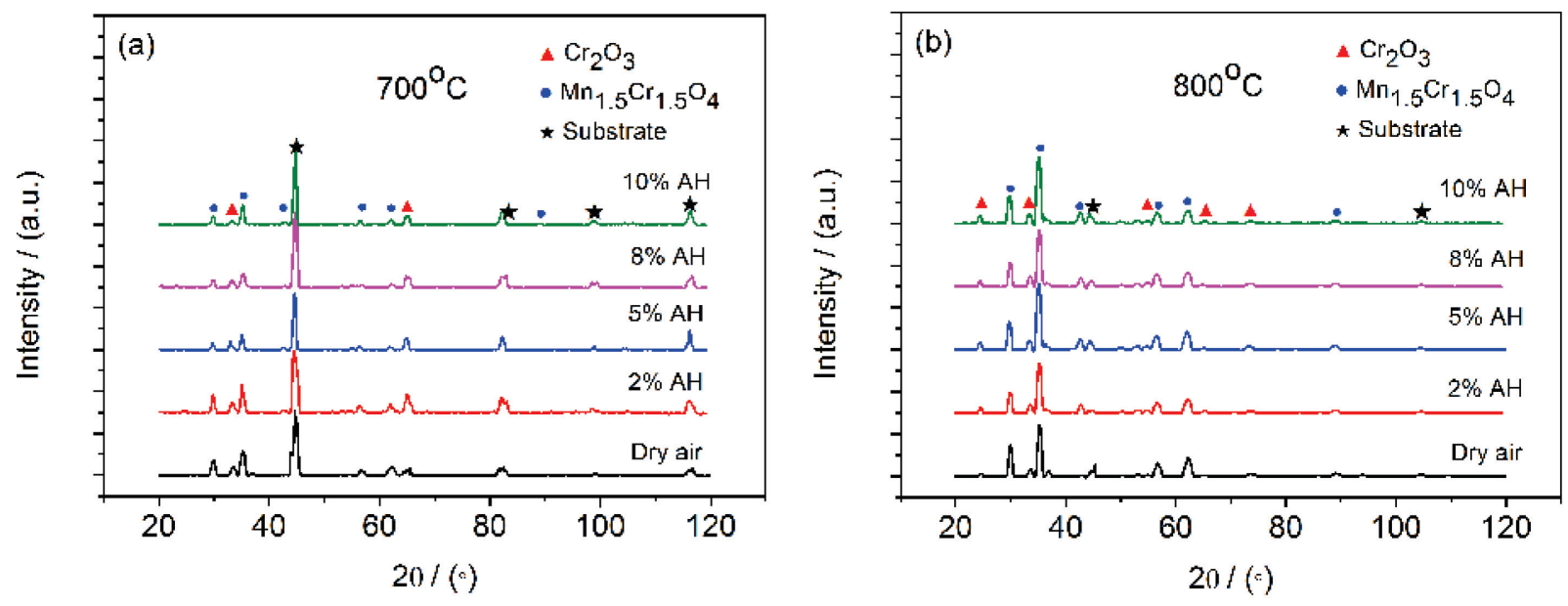

Figure $12^{\circ}$ GIXRD pattern of AISI 430 after oxidation in air with different absolute humidity (AH) at $700^{\circ} \mathrm{C}$ for $96 \mathrm{~h}\left(\right.$ a), at $800^{\circ} \mathrm{C}$ for $96 \mathrm{~h} \mathrm{(b)}$

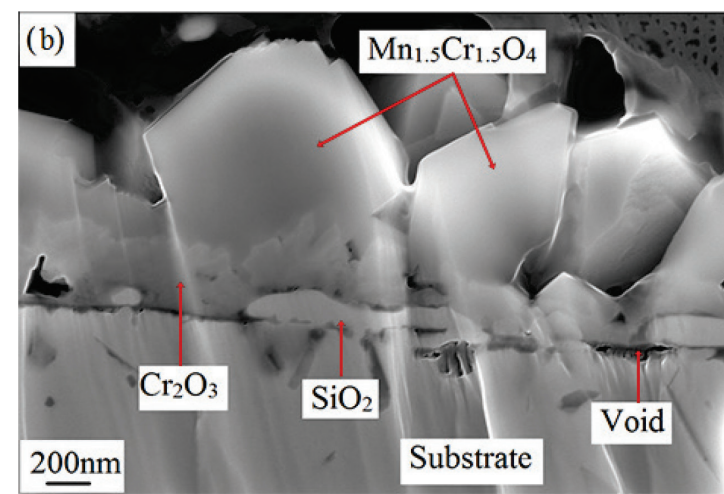

Figure 2 Cross section of the AISI 430 alloy oxidized in air with $5 \%$ humidity at $800^{\circ} \mathrm{C}$ for $48 \mathrm{~h}$

Residual stresses in protective Chromia layer after oxidation in air with different absolute humidity at different temperature are given in Figure 3. It is clear that the concentration of water vapor in the atmosphere can affect the residual stresses levels in the Chromia layer. At $700^{\circ} \mathrm{C}$, the compressive residual stresses increase with the increase of water vapor. For $800^{\circ} \mathrm{C}$, the higher the concentration of water vapor, the bigger the residual stresses at first $24 \mathrm{~h}$ and smaller the residual stress after $48 \mathrm{~h}$. With the presence of water vapor, stresses relief was observed at $800^{\circ} \mathrm{C}$.

Figure 4 shows the residual stresses in spinel layer after oxidation in air with different absolute humidity at different temperature, indicates that the residual stresses in this layer are increased with 
the introduction of water vapor in the oxidation atmosphere. At all temperatures studied, the higher the concentration of water vapor, the bigger the level of residual stresses. The stresses relaxation is also observed in this layer, this might due to the effect of accommodation between the two oxide layers. The stresses in spinel layer decease with the deceasing of stress in the Chromia layer.

The residual stress values in Chromia layer is more important than those in $\mathrm{Mn}_{1.5} \mathrm{Cr}_{1.5} \mathrm{O}_{4}$ spinel layer because the Chromia is in inner layer and the RS are generated not only by oxide formation but also by ion diffusion and the external layer formation. With the increase of absolute humidity (AH), the RS level increases in compression and it is probably related especially to oxide layer formation kinetics. Until now, there is no convincing argument to explain the role of the humidity for RS evolution. After $24 \mathrm{~h}$ oxidation at $800^{\circ} \mathrm{C}$, the residual stresses are relaxed and their level is reduced slowly.
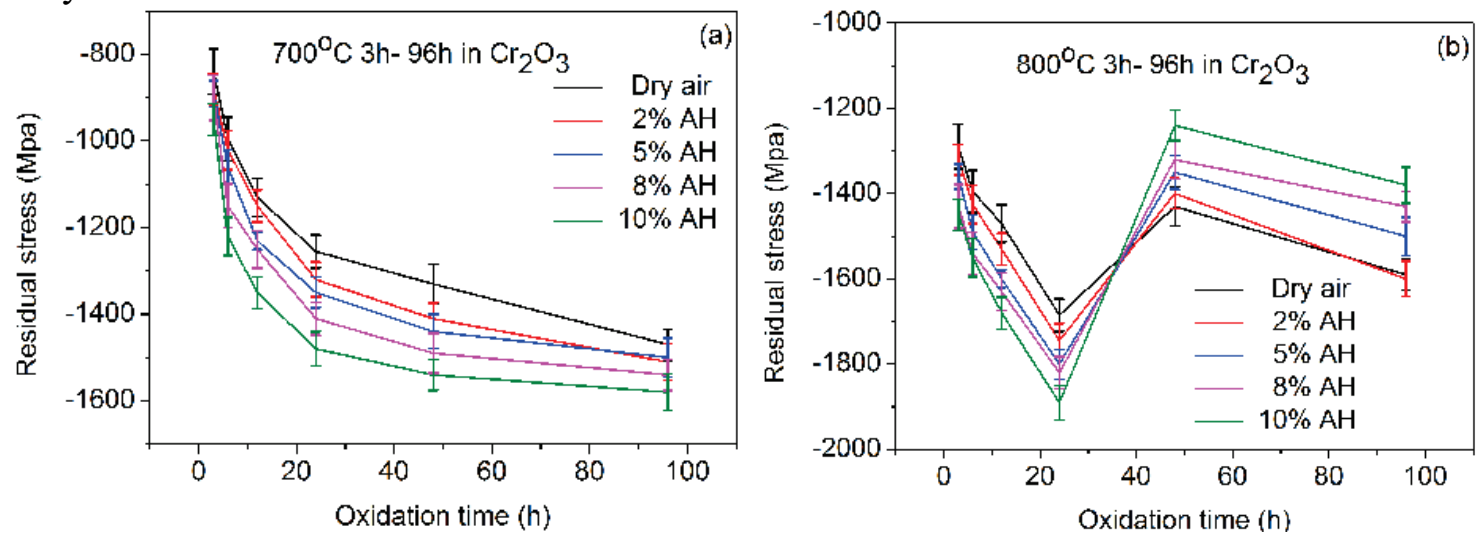

Figure 3 Residual stresses in chromia layer after oxidation in air with different absolute humidity (AH) at $700^{\circ} \mathrm{C}$ (a) and $800^{\circ} \mathrm{C}$ (b)
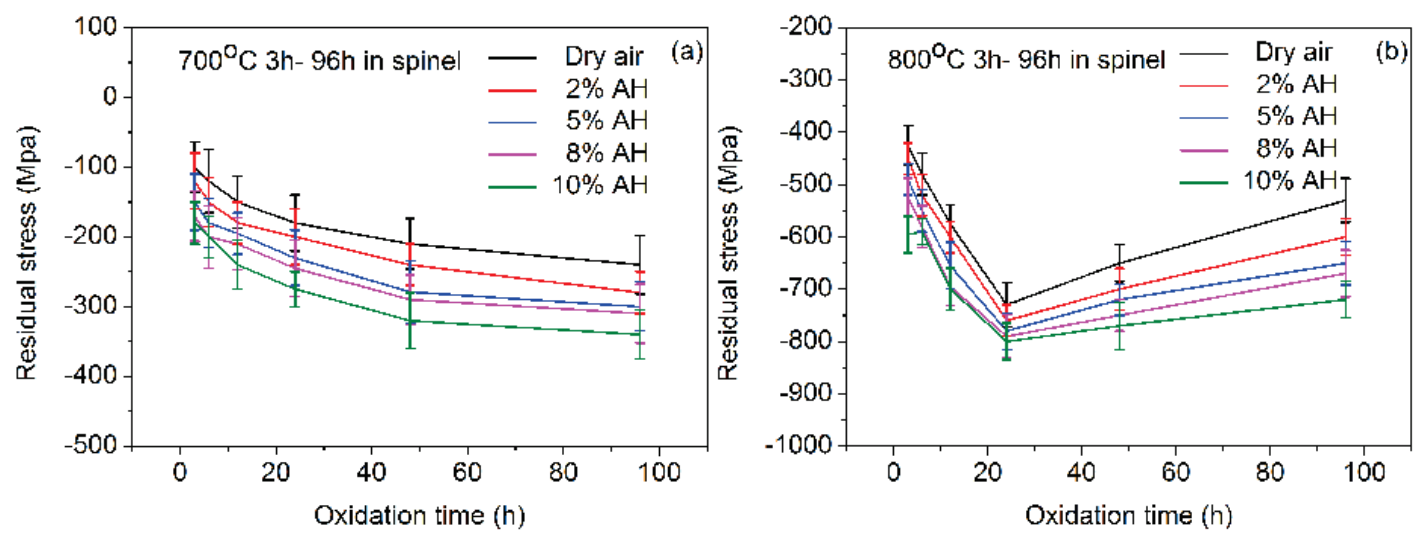

Figure 4 Residual stresses in spinel layer after oxidation in air with different absolute humidity (AH) at $700^{\circ} \mathrm{C}\left(\right.$ a) and $800^{\circ} \mathrm{C}($ b)

Inconel 600 alloy. Figure 5 gives the $2^{\circ}$ GIXRD patterns of Inconel 600 alloy after oxidation in air with different humidity at $700^{\circ} \mathrm{C}, 800^{\circ} \mathrm{C}$ for $24 \mathrm{~h}$. The oxide layers obtained with or without water vapor contained the same mixture of phases $\left(\mathrm{NiO}, \mathrm{Cr}_{2} \mathrm{O}_{3}\right.$ and $\left.\mathrm{NiCr}_{2} \mathrm{O}_{4}\right)$, but the peak of $\mathrm{NiO}$ is more intense than that of $\mathrm{Cr}_{2} \mathrm{O}_{3}$ and $\mathrm{NiCr}_{2} \mathrm{O}_{4}$. The presence of water vapor has no effect on the nature of the phases in the oxide layer formed on the substrate.

Cross section of the Inconel 600 alloy oxidized at $800^{\circ} \mathrm{C}$ for $24 \mathrm{~h}$ in dry air and in air with $5 \%$ absolute humidity is given in Figure 6. It is clear that there are two different oxide layers on the substrate, and the inner layer is thicker than the outer layer. The outer layer is mainly composed of $\mathrm{Ni}$ and $\mathrm{O}$, but in the inner layer, the concentration of $\mathrm{Cr}$ increased obviously. With the XRD analysis, we can conclude that the outer layer is $\mathrm{NiO}$ and the inner layer is likely to be a mixed oxide of spinel type $\mathrm{NiCr}_{2} \mathrm{O}_{4}\left(\mathrm{NiO}+\mathrm{Cr}_{2} \mathrm{O}_{3}\right)$ and $\mathrm{Cr}_{2} \mathrm{O}_{3}$. 

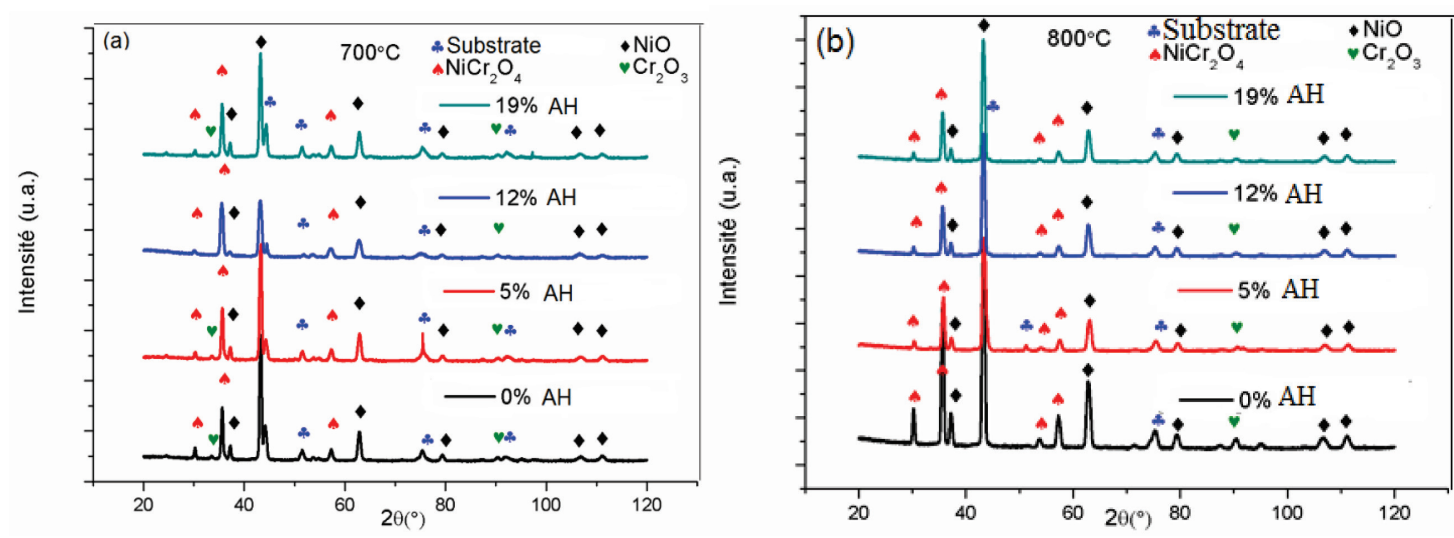

Figure $52^{\circ}$ GIXRD pattern of Inconel 600 alloy after oxidation in air with different absolute humidity (AH) at $700^{\circ} \mathrm{C}$ for $24 \mathrm{~h}\left(\right.$ a) , at $800^{\circ} \mathrm{C}$ for $24 \mathrm{~h}$ (b)
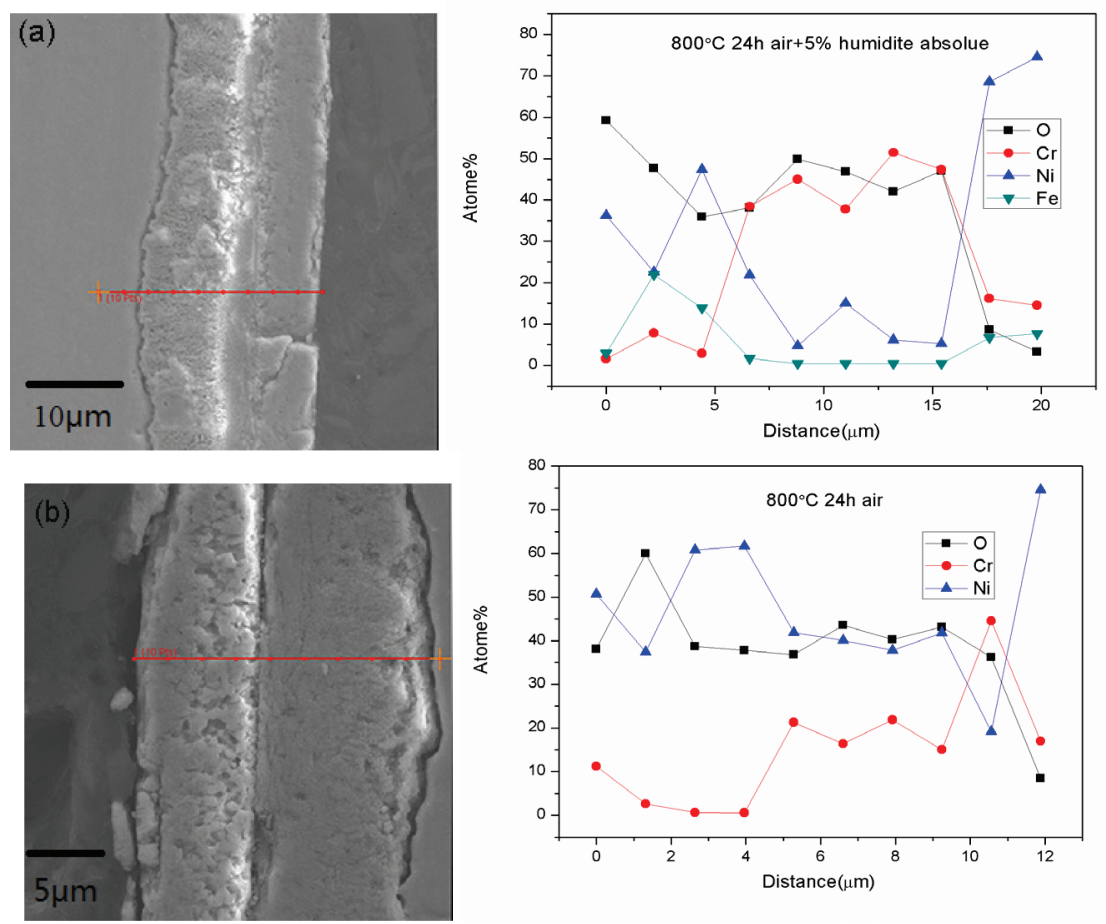

Figure 6 Cross section photos and EDX profiles of the Inconel 600 alloy oxidized at $800^{\circ} \mathrm{C}$ for $24 h$ in air with 5\% AH (a); in dry air (b)

The in-plane residual stresses levels in $\mathrm{NiCr}_{2} \mathrm{O}_{4}$ and $\mathrm{NiO}$ layers after oxidation in air with different absolute humidity at different temperatures are shown in Figure 7, indicating that the residual stresses in both layers are compressive. At $900^{\circ} \mathrm{C}$, compared to other three temperatures, a significant increase of the stresses levels in the two oxide layers was observed. At $600^{\circ} \mathrm{C}$, with or without water vapor, residual stresses in the layer of $\mathrm{NiO}$ are larger than those at $700^{\circ} \mathrm{C}$ and $800^{\circ} \mathrm{C}$.

In addition, with the introduction of water vapor at $700^{\circ} \mathrm{C}$ and $800^{\circ} \mathrm{C}$, the levels of residual stresses in the $\mathrm{NiCr}_{2} \mathrm{O}_{4}$ spinel oxide layer are quite similar to those in dry air; but at $900^{\circ} \mathrm{C}$, the residual stresses in the $\mathrm{NiCr}_{2} \mathrm{O}_{4}$ spinel phase are much higher than those measured at $800^{\circ} \mathrm{C}$.

The residual stress levels in $\mathrm{NiCr}_{2} \mathrm{O}_{4}$ spinel inner layer is more important than those in $\mathrm{NiO}$ external layer because the RS in inner layer are generated not only by oxide formation but also by ion diffusion and the external layer formation. With the increase of oxidation temperature, the RS values increase in compression and it is related directly to the increase of oxide layer thickness. There are less evolutions of residual stress when the absolute humidity is more than 5\%; this is dues to perhaps 
the relative short time of oxidation. With the increase of oxidation time, the RS levels can be relaxed and reduced.
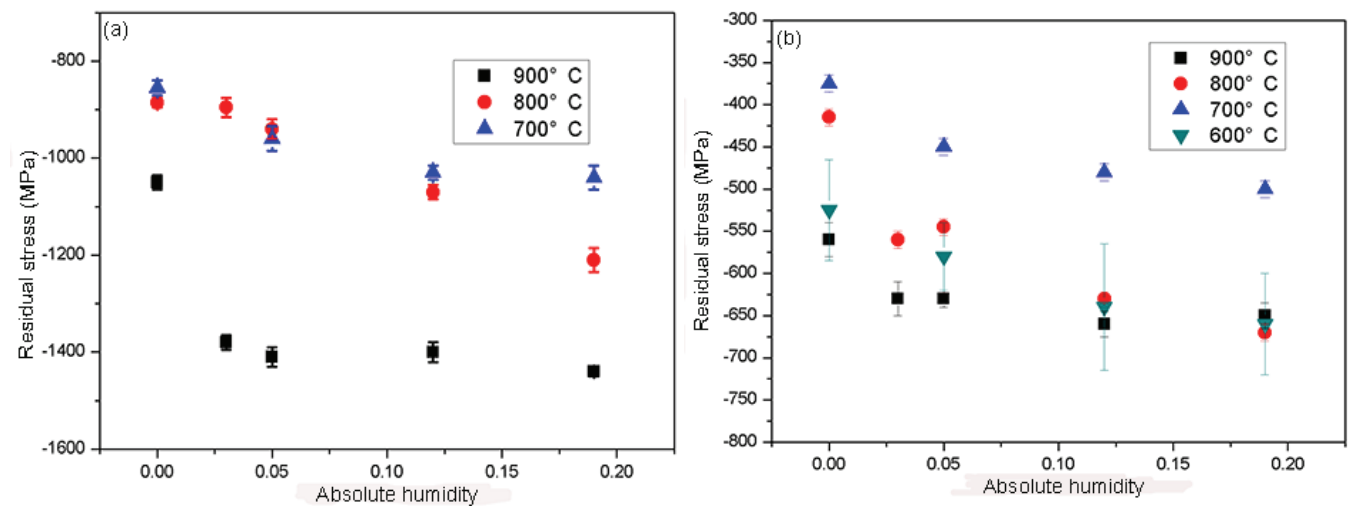

Figure 7 Residual stresses after 24 h oxidation in air with different absolute humidity (AH) at different temperature in $\mathrm{NiCr}_{2} \mathrm{O}_{4}$ innner layer (a); in $\mathrm{NiO}$ external layer (b)

\section{Conclusions}

The oxidation of AISI 430 and Inconel 600 alloys have been carried out in air with different absolute humidity at different temperatures, the basic conclusions from this work can be given as follows:

(1) For AISI 430 alloy, the oxide scale is consisted of an inner $\mathrm{Cr}_{2} \mathrm{O}_{3}$ layer and an outer $\mathrm{Mn}_{1.5} \mathrm{Cr}_{1.5} \mathrm{O}_{4}$ layer; and for Inconel 600 alloy, the oxide scale is composed of outer $\mathrm{NiO}$ layer and inner $\mathrm{NiCr}_{2} \mathrm{O}_{4}$ spinel layer;

(2) With the introduction of water vapor in the oxidation atmosphere, the composition of the oxide scale is not changed for these two alloys. But the water vapor can affect the surface morphology.

(3) For both alloys, with or without water vapor, the residual stresses in oxide scales are always compressive. The water vapor has obvious influence on residual stresses levels.

\section{Reference}

[1]. X. Cheng, Z. Jiang, D. Wei, J. Zhao, B.J. Monaghan, R.J. Longbottom, L. Jiang, Characteristics of oxide scale formed on ferritic stainless steels in simulated reheating atmosphere, Surf. Coat. Technol. 258 (2014) 257-267. http://dx.doi.org/10.1016/j.surfcoat.2014.09.019

[2]. C.T. Fujii, R.A. Meussner, The mechanism of the high-temperature oxidation of iron-chromium alloys in water vapor J. Electrochem. Soc. 111 (1964) 1215-1221. http://dx.doi.org/10.1149/1.2425963

[3]. S. Jianian, Z. Longjiang, L. Tiefan, High-temperature oxidation of $\mathrm{Fe}-\mathrm{Cr}$ alloys in wet oxygen, Oxid. Met. 48 (1997) 347-356. http://dx.doi.org/10.1007/BF01670507

[4]. H. Asteman, J.E. Svensson, L.G. Johansson, M. Norell, Indication of chromium oxide hydroxide evaporation during oxidation of $304 \mathrm{~L}$ at $873 \mathrm{~K}$ in the presence of $10 \%$ water vapor, Oxid. Met. 52 (1999) 95-111. http://dx.doi.org/10.1023/A:1018875024306

[5]. H. Asteman, J.E. Svensson, L.G. Johansson, Oxidation of 310 steel in $\mathrm{H} 2 \mathrm{O} / \mathrm{O} 2$ mixtures at $600^{\circ} \mathrm{C}$ : the effect of water-vapour-enhanced chromium evaporation, Corros. Sci. 44 (2002) 2635-2649. http://dx.doi.org/10.1016/S0010938X(02)00056-2

[6]. J. Ehlers, D.J. Young, E.J. Smaardijk, A.K. Tyagi, H.J. Penkalla, L. Singheiser, W.J. Quadakkers, Enhanced oxidation of the $9 \% \mathrm{Cr}$ steel P91 in water vapour containing environments, Corros. Sci. 48 (2006) 3428-3454. http://dx.doi.org/10.1016/j.corsci.2006.02.002

[7]. N. Li, J. Xiao, N. Prud'homme, Z. Chen, V. Ji, Residual stresses in oxide scale formed on Fe-17Cr stainless steel, Appl. Surf. Sci. 316 (2014) 108-113. http://dx.doi.org/10.1016/j.apsusc.2014.07.195

[8]. S. Chevalier, C. Valot, G. Bonnet, J.C. Colson, J.P. Larpin, The reactive element effect on thermally grown chromia scale residual stress, Mater. Sci. Eng. A 343 (2003) 257-264. http://dx.doi.org/10.1016/S09215093(02)00359-3

[9]. Test Method for Residual Stresses Analysis by X-ray diffraction, in: European Standard no NF15305, 2009.

[10]. A.M. Huntz, Stresses in $\mathrm{NiO}, \mathrm{Cr}_{2} \mathrm{O}_{3}$ and $\mathrm{Al}_{2} \mathrm{O}_{3}$ oxide scales, Mater. Sci. Eng. A 201 (1995) 211-228. http://dx.doi.org/10.1016/0921-5093(94)09747-X

[11]. W.N. Liu, X. Sun, E. Stephens, M.A. Khaleel, Life prediction of coated and uncoated metallic interconnect for solid oxide fuel cell applications, J. Power Sources 189 (2009) 1044-1050.

http://dx.doi.org/10.1016/j.jpowsour.2008.12.143 